\title{
ANTIBACTERIAL ACTIVITY OF MARINE BACTERIA ASSOCIATED WITH SPONGES FROM PHU QUOC ISLAND IN VIETNAM
}

\author{
Phan Thi Hoai Trinh ${ }^{1}$, Ngo Thi Duy Ngoc ${ }^{1}$, Phi Quyet Tien², Le Dinh Hung', Vo Thi Dieu Trang ${ }^{1}$, Cao \\ Thi Thuy Hang ${ }^{1}$, Huynh Hoang Nhu Khanh ${ }^{1}$, Tran Thi Thanh Van ${ }^{1}$, Bui Minh Ly ${ }^{1}$ \\ ${ }^{1}$ Nha Trang Institute of Technology Research and Application, Vietnam Academy of Science and Technology \\ ${ }^{2}$ Institute of Biotechnology, Vietnam Academy of Science and Technology
}

Received: 16.7 .2015

Accepted: 20.02.2016

\section{SUMMARY}

\begin{abstract}
Sponge associated marine microbes recognised as potential candidate for screening and isolation of bioactive compounds. In this work, thirty-one marine bacterial strains associated with seven species of sponges collected from Phu Quoc Island, Vietnam were isolated and screened for antimicrobial activity against selected human and animal pathogens including Escherichia coli, Pseudomonas aeruginosa, Staphylococcus aureus, Vibrio parahaemolyticus, Vibrio harveyi, Bacillus cereus, Streptococcus faecalis, Listeria monocytogenes, Proteus mirabilis and Klebsiella pneumoniae using agar well diffusion assay. Twenty-six percent of bacterial strains were found to be antibacterial producers and their activities ranged from broad spectral to species specific ( $P$. aeruginosa, E. coli, P. mirabilis, B. cereus, and $L$. monocytogenes). Out of the 31 marine bacterial strains subjected to preliminary screening for antibacterial activity, 8 isolates exhibited antibacterial activity against at least two tested pathogens, that $55 \%$ against $P$. mirabilis, 22\% against $P$. aeruginosa, $10 \%$ against $E$. coli and $6 \%$ against $K$. pneumoniae, B. cereus and $L$. monocytogenes. A strain coded 045-203-4 was found to be highly potent and was cultured for further study. The strain produced metabolites with good activity in medium contained yeast extract $(0.8 \% \mathrm{w} / \mathrm{v})$, glucose $(0.5 \%)$ at $\mathrm{pH} 7.0$ and after incubated shaking for $30 \mathrm{~h}$ at $150 \mathrm{rpm}$. In addition, strain $045-203-4$ was analyzed for morphological and physiological characteristics. Analysis of the nucleotide sequence of 16s rRNA gene of strain 045-203-4 showed a strong similarity (99\%) with that of the 16s rRNA gene of Bacillus subtilis. The present investigation reveals that the marine bacteria isolated from sponges at Phu Quoc Island can be a definite source for novel antibiotics.
\end{abstract}

Keywords: Antibacterial activity, Bacillus subtilis, Marine bacteria, Metabolites, Sponges, Pathogenic bacteria

\section{INTRODUCTION}

Marine environment has extreme conditions for the survival of organisms including microorganisms due to low temperature, salinity and pressure. Therefore, in order to adapt to the harsh living conditions requires microorganisms must change the way metabolism to adapt and survive (Jafarzade et al., 2013). Besides, the marine environment with the diversity of the marine species and complex habitat conditions, the marine microbial biosynthesis metabolites have more interesting biological activity than terrestrial organisms (Carte et al., 1996, Rinehart et al., 2000, Schwartsmann et al., 2001).

Currently, infectious diseases caused by bacteria, fungi and viruses are still a major threat to public health, although human medicine has reached a certain level of progress. This situation is common in developing countries due to lack of drug and the emergence of multidrug resistance. The researchers discovered new alternative antibiotics, especially antibiotics derived from marine microorganisms are attracting the interest of many scientists (Joseph et al., 2009).

During the past 40 years, many scientists over the world have focus on discovery novel natural products from marine organisms. The results showed that more than 12,000 novel chemicals with hundreds of new compound are still being discovered every year (Pettit et al., 2004). So far most of these chemicals have been found from marine organisms including sponges dominate (Lie et al., 2002). 
Many collected compounds from marine sponges expressed strong biological activity such as anticancer, antibacterial and anti-inflammatory activities, and usually used in medicine (Pettit et al., 2004; Faulkner et al., 2002; Sonnenschein et al., 2004). Some research showed that compounds previously extracted from sponges are biosynthesized through associated microorganisms or actually be produced by microorganisms (Bewley et al., 1998; Unson et al., 1993; Unson et al., 1994). In recent years, many new compounds with diverse biological activities have been discovered from microorganisms isolated from marine sponges (Jayatilake et al., 1996; Mitova et al., 2003; Suzumura et al., 2003). With the goal of finding compounds have antibiotic activity from marine microorganisms, we isolated several strains of bacteria associated with marine sponges collected from Phu Quoc Island, Vietnam.

\section{MATERIALS AND METHODS}

\section{Isolation of marine bacteria}

Bacterial strains were isolated from seven species of marine sponges from Phu Quoc Island, Vietnam. Collected samples were rinsed three times with sterile seawater in order to remove the nonattached bacteria. One g sample was triturated with sterile sea water and spread on the entire surface of Marine Agar (MA) (peptone $5 \mathrm{~g}$, yeast extract $1 \mathrm{~g}$, $\mathrm{MgSO}_{4} 0.1 \mathrm{~g}, \mathrm{KH}_{2} \mathrm{PO}_{4} 0.1 \mathrm{~g}$ and agar $18 \mathrm{~g}$ dissolved in $500 \mathrm{~mL}$ sea water and $500 \mathrm{~mL}$ distilled water, $\mathrm{pH}$ 7.0-7.2). After incubation at $28^{\circ} \mathrm{C}$ for $24 \mathrm{~h}$, all colonies with different pigmentation and morphology were picked out. The isolated colonies were repeatedly streaked to obtain pure cultures and stored at $-80^{\circ} \mathrm{C}$ in Marine Broth supplemented with $30 \%(\mathrm{v} / \mathrm{v})$ glycerol for further studies.

\section{Test bacteria}

Ten clinical bacterial pathogens such as Escherichia coli, Pseudomonas aeruginosa, Staphylococcus aureus, Vibrio parahaemolyticus, Vibrio harveyi, Bacillus cereus, Streptococcus faecalis, Listeria monocytogenes, Proteus mirabilis and Klebsiella pneumoniae were used in this study. The strains were obtained from Pacific Institute of Bio-Organic Chemistry, Far-Eastern Branch, Russian Academy of Science (PIBOC FEBRAS), Russia.

\section{Preliminary screening of antibacterial substance from marine bacteria}

Primary screening of antibacterial activity of 31 marine bacterial strains were determined by agar well diffusion method described by Bauer et al., (1966) with modification. One hundred $\mu \mathrm{L}$ contained cell masses of each isolated bacteria in $0.9 \% \mathrm{NaCl}$ solution for $24 \mathrm{~h}$ was inoculated into wells $(8 \mathrm{~mm}$ in diameter) in MA plates containing the pathogenic bacteria. All the plates were incubated at $37^{\circ} \mathrm{C}$ for 24 h. The zone of inhibition was measured and expressed in diameter in millimeter. Based on the results of preliminary screening, marine bacterial isolates with high activity were selected as potential strains for further investigations.

\section{Preparation of crude extract}

Selected marine bacteria were cultured in $300 \mathrm{~mL}$ Marine Broth (peptone $5 \mathrm{~g}$, yeast extract $1 \mathrm{~g}$, $\mathrm{MgSO}_{4} 0.1 \mathrm{~g}$ and $\mathrm{KH}_{2} \mathrm{PO}_{4} 0.1 \mathrm{~g}$, dissolved in $500 \mathrm{~mL}$ distilled water and $500 \mathrm{~mL}$ seawater, $\mathrm{pH} 7.0-7.2)$ to produce secondary metabolites in $500 \mathrm{~mL}$ Erlenmeyer flasks. Flasks were incubated on a rotatory shaker at $150 \mathrm{rpm}$. After $24 \mathrm{~h}$ of cultivation, the broth was centrifuged at $8000 \mathrm{rpm}$ for $20 \mathrm{~min}$ to remove the cell and extract equal volume of ethyl acetate (EtOAc) for two times. The solvent layers were collected and then evaporated to obtained crude required for second antibacterial screening.

\section{Secondary screening of antibacterial activity}

Antibacterial activity assay of the extracts was done using the disk diffusion method performed on MA according to Bauer et al., (1966). The crude extract is weighed and dissolved in EtOAc (0.2 $\mathrm{mg} / \mathrm{mL}$ ) for antibacterial studies. The sensitivity of the test bacteria strains to the EtOAc extracts of the isolates was determined of measuring the sizes of inhibitory zones on the agar surface around the disks and expressed in diameter in millimeter.

\section{Identification of isolate 045-203-4}

Morphological and physiological characterizations

The strain 045-203-4 was morphologically and physiologically characterized by the methods described by Sneath et al., (1986).

\section{Molecular identification}

Genomic DNA was extracted from strain 045203-4 in logarithm phrase as a template for polymerase chain reaction (PCR), and then $16 \mathrm{~S}$ 
rRNA gene was amplified by PCR. PCR amplification of the 16S rRNA gene was performed using universal primers 16SF (5'AGAGTTTGATCCTGGCTCAG-3') and 16SR (5TACGGTTACCTTGTTACGACTT-3'). Sequences were compared with other $16 \mathrm{~S}$ rRNAs obtained from
GenBank using the BLAST program. Alignments and similarity comparison were done using the CLUSTALW programmed at European Bioinformatics site (http://www.ebi.eic.uk/clustalw). The phylogenetic tree was constructed using MEGA with neighbor-joining method.

Table 1. Antibacterial activity of marine bacteria (zone of inhibition in $\mathrm{mm}$ ).

\begin{tabular}{|c|c|c|c|c|c|c|c|c|c|c|}
\hline \multirow{2}{*}{ Strain no } & \multicolumn{10}{|c|}{ Pathogens } \\
\hline & SA & PA & EC & VP & PM & VH & KP & BC & SF & LM \\
\hline $045-203-2$ & - & - & - & - & - & - & - & - & - & - \\
\hline $045-203-3$ & - & - & - & - & - & - & - & - & - & - \\
\hline $045-203-4$ & - & 22 & 12 & - & - & 11 & 11 & 09 & 09 & - \\
\hline $045-203-5$ & - & 10 & - & - & 15 & - & - & - & - & - \\
\hline $045-206-1$ & - & 12 & 20 & - & 10 & - & - & - & - & - \\
\hline $045-206-2$ & - & - & - & - & - & - & - & - & - & - \\
\hline $045-206-3$ & - & - & - & - & - & - & - & - & - & - \\
\hline $045-230-1$ & - & - & - & - & - & - & - & - & - & - \\
\hline $045-230-2$ & - & - & - & - & 15 & - & - & - & - & - \\
\hline $045-230-3$ & - & - & - & - & 18 & - & - & - & - & - \\
\hline $045-236-1$ & - & - & - & - & - & - & - & 11 & - & - \\
\hline $045-236-2$ & - & 12 & - & - & - & - & - & 11 & - & - \\
\hline $045-236-3$ & - & 11 & - & - & 15 & - & - & - & - & - \\
\hline $045-236-4$ & - & 11 & - & - & 12 & - & - & - & - & - \\
\hline $045-236-5$ & - & - & - & - & 12 & - & - & - & - & - \\
\hline $045-236-6$ & - & - & - & - & - & - & - & - & - & 23 \\
\hline $045-255-1$ & - & - & 22 & - & 12 & - & - & - & - & - \\
\hline $045-255-2$ & - & - & - & - & 12 & - & - & - & - & - \\
\hline $045-255-3$ & - & - & - & - & 12 & - & - & - & - & - \\
\hline $045-255-4$ & - & - & - & - & 20 & - & - & - & - & - \\
\hline $045-255-5$ & - & - & - & - & 15 & - & - & - & - & - \\
\hline $045-255-6$ & - & - & - & - & 15 & - & - & - & - & - \\
\hline $045-273-1$ & - & 20 & - & 12 & 18 & - & - & - & - & 12 \\
\hline $045-273-2$ & - & - & - & - & 25 & - & - & - & - & - \\
\hline $045-273-3$ & - & - & - & - & 18 & - & - & - & - & - \\
\hline $045-273-4$ & - & - & - & - & 15 & - & - & - & - & - \\
\hline $045-273-5$ & - & - & - & - & - & - & - & - & - & - \\
\hline $045-274-2$ & - & - & - & - & - & - & - & - & - & - \\
\hline $045-274-3$ & - & - & - & - & - & - & 12 & - & - & - \\
\hline $045-274-4$ & - & + & - & - & - & - & - & - & - & - \\
\hline $045-274-5$ & - & + & - & - & - & - & - & - & - & - \\
\hline
\end{tabular}

Note: - : no inhibition zone

\section{Medium optimization}

All experiments in this study were carried out in shaking cultures to determine the physiological and physical conditions that would affect the antibacterial agent production of the selected strain six various nitrogen sources at a concentration of $1 \%$ $(\mathrm{w} / \mathrm{v})$ to study the effects of different nitrogen 
sources on antibacterial agent production by isolate 045-203-4. The effect of addition of equimolar amounts of different inorganic and organic nitrogen sources to enhance the antibacterial agent production by isolate 045-203-4 was also studied. Since, yeast extract might be considered as a growth factor and nitrogen source. So, different concentrations of yeast extract were added to test their effect on the antibacterial agent production.

In addition, the effect of equimolar amounts of different carbon sources and different concentrations of selected carbon source on antimicrobial activity was also studied.

\section{RESULTS AND DISCUSSION}

\section{Antibacterial activity of marine bacteria}

Microorganisms play a central role in sponge biology, as they are associated with many sponges either extracellularly, intracellularly or both. Isolation is a mandatory approach to obtain novel microbes and also for evaluating their biochemical characteristics to understand the ecophysiological and environmental functions with their potential applications (Sfanos et al., 2005).

Out of the 31 marine bacterial strains associated with sponges subjected to preliminary screening for antibacterial activity, 8 isolates exhibited antibacterial activity against at least two tested pathogens, that $55 \%$ against $P$. mirabilis, $22 \%$ against $P$. aeruginosa, $10 \%$ against $E$. coli and $6 \%$ against $K$. pneumoniae, $B$. cereus and $L$. monocytogenes (Table 1). Among them, 3 isolates (045-203-4, 045-206-1, and 045-273-1) showed good antibacterial activity to at least three tested pathogens. Therefore, they were selected as potential strains for secondary screening.

A total of 8 tested pathogens were chosen for secondary screening of antibacterial activity using EtOAc crude extracts of three selected isolates. In the present study, the highest activity was exhibited from the strain 045-203-4, with an inhibition zone of $29 \mathrm{~mm}$ against $S$. aureus and $38 \mathrm{~mm}$ against $L$. monocytogenes (Table 2).

The discovery of enormous microbial diversity in marine sponges provides unprecedented research opportunities. Increased metabolic capabilities of sponge-associated bacteria were directly correlated with increased levels of potentially available nutrients in the sponge. Sponges filter seawater and accumulate copious amount of organic matter within the choanocytic chambers along with bacteria (Santavy et al., 1990).

Jafarzade et al., (2011), Guo et al., (2011) and Kennedy et al., (2009) also reported the microorganism isolated from the marine sponges, showed potent antimicrobial activity against bacterial pathogens.

Table 2. Antibacterial activity of EtOAc extracts from strain 045-203-4, 045-206-1 and 045-273-1.

\begin{tabular}{|c|c|c|c|}
\hline \multirow[t]{2}{*}{ Test bacteria } & \multicolumn{3}{|c|}{ Extracts (zone of inhibition in $\mathrm{mm}$ ) } \\
\hline & $045-203-4$ & $045-206-1$ & 045-273-1 \\
\hline S. aureus & 29 & 20 & 15 \\
\hline P. aeruginosa & 25 & 13 & 22 \\
\hline E. coli & 30 & 22 & - \\
\hline K. pneumoniae & 25 & - & - \\
\hline P. mirabilis & 21 & 12 & 19 \\
\hline B. cereus & 16 & 12 & - \\
\hline S. faecalis & 20 & 10 & 10 \\
\hline L. monocytogenes & 38 & 25 & 14 \\
\hline
\end{tabular}

It has been reported that the production and potential of bioactive compounds by different microorganisms can be strongly influenced by the source of isolation. The antibiotic activity of marine bacteria is well-known and has been demonstrated in a number of studies the vast diversity of microorganisms in the marine niches, continue to yield many novel bioactive compounds. Hence, 
exploration of biotechnological potentials of microbes associated with invertebrates still remains a very important and untapped resource. From all these observations the bacterial isolates from the sponges are found to be most prolific marine producers of novel compounds (Devi et al., 2010).

\section{Identification of strain 045-203-4}

The results of morphological, physiological and biochemical characteristics of strain 045-203-4 were shown in Table 3 . The $045-203-4$ strain was able to grow at the $20-45^{\circ} \mathrm{C}, \mathrm{pH} 5-11$ and it could tolerate concentration of $90 \mathrm{~g} \mathrm{~L}^{-1} \mathrm{NaCl}$ solution. It has positive results for catalase, oxidase, ONPG, gelatinase, Voges-Proskauer and utilization of citrate as a source of carbon. It could not produce hydrogen sulfide as well as indole. According to investigated results on the morphological, physiological and biochemical characteristics of the strain, 045-302-4 preliminary classified to be Bacillus genus.

Table 3. Morphological and physiological characteristics of strain 045-203-4.

\begin{tabular}{|c|c|c|c|}
\hline Properties & Results & Properties & Results \\
\hline Shape & Rods & $\mathrm{H}_{2} \mathrm{~S}$ production & - \\
\hline Flagellum & + & Urease & - \\
\hline Motility & + & VP test & + \\
\hline Growth temperature & $20-45^{\circ} \mathrm{C}$ & Gelatinase & + \\
\hline $\mathrm{NaCl}$ concentration for growth & $0-90 \mathrm{~g} \mathrm{~L}^{-1}$ & D-Glucose & + \\
\hline Catalase & + & D-Mannitol & + \\
\hline Oxidase & + & Inositol & - \\
\hline ONPG & + & Sorbitol & + \\
\hline Lysine & - & Melibiose & + \\
\hline Ornithine & - & Amylase & + \\
\hline Citrate utilization & + & L-Arabinose & + \\
\hline
\end{tabular}

Note: Cultivating $045-203-4$ at $28^{\circ} \mathrm{C}$ for $24 \mathrm{~h}$; + positive results; - negative results Lactobacillus brevis (HQ293043.1)

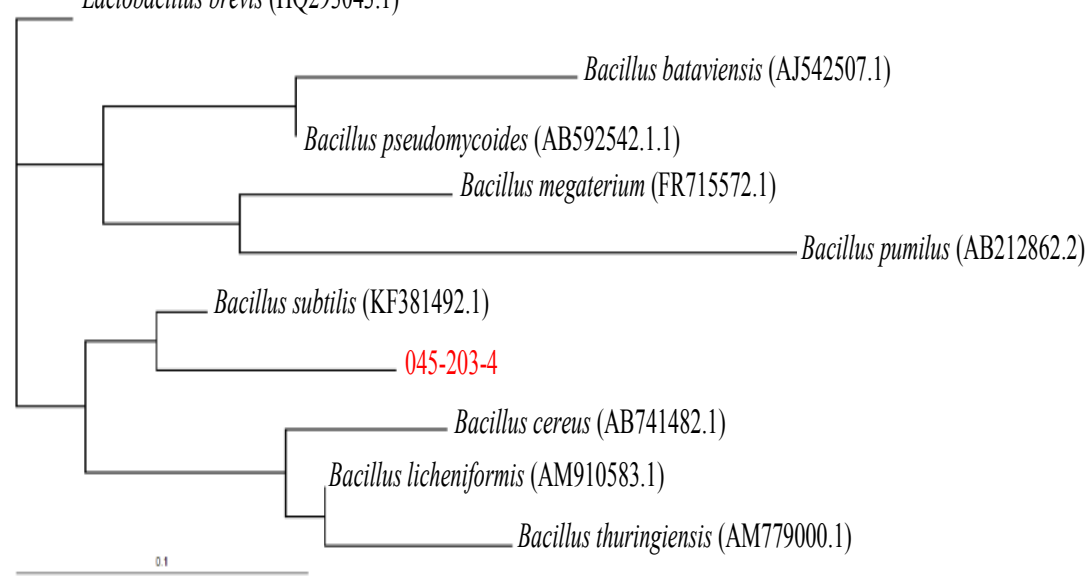

Figure 1. Phylogenetic tree based on 16S rRNA gene sequences and closely related members of the genus Bacillus. Numbers at nodes are levels of bootstrap support based on neighbor-joining analyses of 1000 replications. 
The analysis of the 16S rRNA gene is an important tool for correct identification of microbial species. The length of the partial 16S rRNA gene sequence of the isolate was $1500 \mathrm{bp}$. The phylogenetic tree, which was constructed for comparison of the $16 \mathrm{~S}$ rRNA gene sequences, indicated that strain 045-203-4 belonged to the genus of Bacillus. The levels of similarity between the 16S rRNA gene of Bacillus 045-203-4 and the 16S rRNA gene of other Bacillus species are summarized in Figure 1. It was found that Bacillus 045-203-4 has the highest similarity with B. subtilis, in fact over 99\% (NCBI accession no. 381492.1).

It has been estimated that over $99 \%$ of the marine sponge-associated microbes have yet to be cultured in the laboratory with bacteria isolated from the sponges containing diverse Bacillus species being one of the most divergent forms. Among all isolates Bacillus species was found to be predominant in symbiotic association with sponges. Many members of the Bacillus group continue to be dominant bacterial workhorses in microbial fermentation for the production of novel compounds (Kennedy et al., 2009).

The terrestrial Bacillus sp. is widely recognized as a rich source of antimicrobial agents (Gebhardt et al., 2002). The occurrence of Bacillus sp. in the marine environment has been well documented (Ivanova et al., 1999). Many antibiotics including cyclic peptides, cyclic lipopeptides and novel thiopeptides have been reported from marine Bacillus sp. (Nagai et al., 2003). Until 2002, 12 bioactive compounds were reported from marine Bacillus sp. (Dobler et al., 2002). Bacillus sp. isolates produce structurally diverse classes of secondary metabolites that exhibit a wide range of biological activities (Mandol et al., 2013). To 2014, Tareq et al. discovered four new non-cytoxic lipopeptides, gageopeptides A-D with good antimicrobial activity from a marine-derived bacterium Bacillus subtilis. In 2015, two new glycolipids, ieodoglucomide C ieodoglycolipid were isolated from Bacillus licheniformis (Tareq et al., 2015).

\section{Medium optimization}

The condition of incubation influenced quantitatively the biosynthesis of antibiotics as well as biomass. It has been reported that nutritional requirement play an important role during metabolite synthesis (Tabbene et al., 2009). The part of work aims at the optimization of some culture conditions to attain maximum antibacterial agent production. Of all the tested nitrogen sources $(1 \% \mathrm{w} / \mathrm{v})$ in the $\mathrm{MB}$ medium inoculated with B. subtilis 045-203-4 and incubated shaken for $24 \mathrm{~h}$, yeast extract supported the highest level of antibacterial agent production (Table 4).

Table 4. Effect of different inorganic and organic nitrogen sources for antibacterial agent production by B. subtilis 045-203-4.

\begin{tabular}{|c|c|c|c|c|c|c|}
\hline Test bacteria & \multicolumn{6}{|c|}{ Inorganic and organic nitrogen sources (zone of inhibition in $\mathrm{mm}$ ) } \\
\hline S. aureus & 30 & 15 & 25 & 33 & 12 & 20 \\
\hline$P$. aeruginosa & 20 & - & 13 & 22 & - & - \\
\hline E. coli & 19 & 19 & 22 & 32 & 19 & 21 \\
\hline K. pneumoniae & 24 & 13 & 13 & 14 & - & 17 \\
\hline V. harveyi & 11 & 10 & 13 & 12 & 12 & 18 \\
\hline B. cereus & 16 & 19 & 15 & 22 & 13 & 18 \\
\hline S. faecalis & 15 & 19 & 14 & 14 & 13 & 14 \\
\hline
\end{tabular}

The effects of different nitrogen sources on antibacterial agent production by $B$. subtilis $045-203-$ 4 were also studied. Zero point eight percent (w/v) was the best concentration of yeast extract for optimum antibacterial agent production by $B$. subtilis 045-203-4 (Table 5). The requirements for specific nitrogen supplement differ from one microorganism to another. In most microorganisms both inorganic 
and organic forms of nitrogen are metabolized to produce amino acids, nucleic acids, proteins and cell wall components. However, it was found that some nitrogen sources had an inhibitory effect on the antibacterial agent production and this may be due to organic acid accumulation, oxygen depletion or sugar catabolic repression.

Sreerag et al., (2014) reported that yeast extract was the best nitrogen sources for antibiotics production by Bacillus sp. isolated from a rhabditid entomopathogenic nematode, Rhabditis (Oscheius) sp.. The nature of the nitrogen source used has a notable effect on the production of the antimicrobial metabolite in the bacterium. Depending on the biosynthetic pathways involved, nitrogen sources may significantly affect antibiotic formation. It was noted by Sanchez and Demain (2002) that ammonium salts did not favor biosynthesis of novobiocin, actinomycin, neomycin, kanamycin and others, but for rapamycin ammonium sulfate was the best nitrogen source.

In addition, different carbon sources including starch, maltose, manitol, glucose, sucrose were used at the concentration $0.4 \%(\mathrm{w} / \mathrm{v})$ in the MB medium to study their effect on antimicrobial activity of the strain. After shaking for $24 \mathrm{~h}$, glucose supported the highest level of antibacterial agent production. The effect of different concentrations of glucose on antimicrobial activity was also studied. Maximum antimicrobial activity of $B$. subtilis 045-203-4 was recorded at glucose concentration of $0.5 \%(\mathrm{w} / \mathrm{v})$. Antimicrobial metabolite production by Bacillus sp. for other studies was also optimally produced with glucose or sucrose in the medium (AbdelAziz et al., 2013).

Table 5. Effect of different yeast extract concentrations for antibacterial agent production by B. subtilis 045-203-4.

\begin{tabular}{llllllll}
\hline & \multicolumn{7}{c}{$\begin{array}{c}\text { Different yeast extract concentrations (\%w/v) } \\
\text { (zone of inhibition in } \mathbf{~ m m})\end{array}$} \\
\cline { 2 - 8 } Test bacteria & $\mathbf{0 . 4}$ & $\mathbf{0 . 6}$ & $\mathbf{0 . 8}$ & $\mathbf{1 . 0}$ & $\mathbf{1 . 2}$ & $\mathbf{1 . 4}$ & $\mathbf{1 . 6}$ \\
\hline S. aureus & - & - & 20 & 22 & 24 & 28 & 22 \\
P. aeruginosa & - & 10 & $\mathbf{1 4}$ & 12 & - & - & - \\
E. coli & 23 & 25 & $\mathbf{2 8}$ & 22 & - & - & - \\
P. mirabilis & 12 & 20 & $\mathbf{3 4}$ & 24 & 13 & 13 & 12 \\
K. pneumoniae & 12 & 13 & $\mathbf{1 6}$ & 14 & 13 & 10 & 10 \\
B. cereus & 13 & 15 & $\mathbf{2 0}$ & 18 & 13 & 13 & 13 \\
S. faecalis & 14 & 14 & 14 & 15 & 14 & 13 & 13 \\
L. monocytogenes & 36 & 38 & $\mathbf{4 2}$ & 40 & 39 & 38 & 32 \\
\hline
\end{tabular}

\section{Time course of the antibacterial agent production on the optimized medium}

Time course from 12 to $48 \mathrm{~h}$ was followed in shaking incubated flask containing the optimized culture conditions inoculated with B. subtilis $045-$ 203-4. The relationship between antibacterial activity and cell density is shown in Figure 2. It is evident that strain B. subtilis 045-203-4 could produce antibacterial substances only when the $\mathrm{OD}_{660}$ value was above the threshold value of 1.0 , at the beginning of the stationary phase. Antibacterial activity was highest when strain $B$. subtilis 045-203-
4 was cultured in MB after $30 \mathrm{~h}$ incubated shaken. It is reported that antibiotic production usually occurs in stationary phase (Tabbene et al., 2009).

As show in Figure 2, OD and $\mathrm{pH}$ values had a close correlation with the growth conditions of $B$. subtilis 045-203-4. At the beginning of fermentation, the biomass content and $\mathrm{pH}$ were low. Then, along with the growth of the bacterium, after $12 \mathrm{~h}$ fermentation the $\mathrm{pH}$ and $\mathrm{OD}$ values increased quickly. When the strain was in stationary phase, the $\mathrm{pH}$ value began to stabilize $(\mathrm{pH}=7.8)$ and unchanged the value during the stationary phase. 


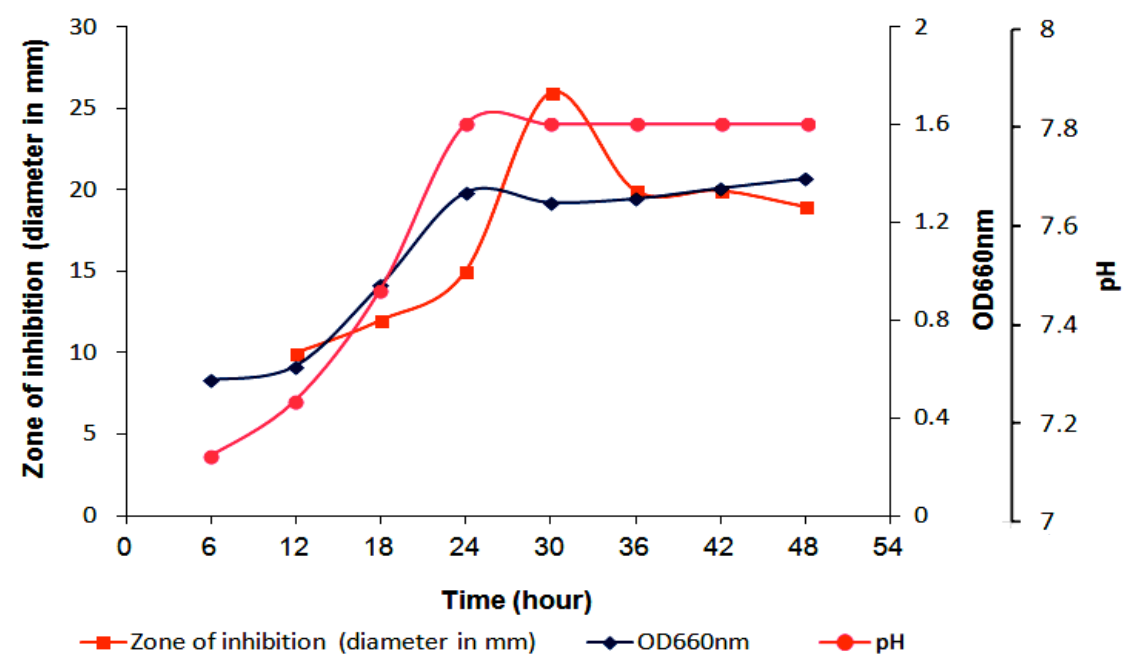

Figure 2. Time course of the antibacterial agent production against S. aureus and the growth by Bacillus subtilis. 045-203-4.

\section{CONCLUSION}

The present study indicated that isolated bacteria from marine sponges remain an interesting source for new antibacterial metabolites and also suggested that B. subtilis 045-203-4 producing secondary metabolites with high antibacterial activity. Marine environment in Phu Quoc Island can be a potential source for natural products with biological activities in order to discover new compounds for application of marine microbial sources in Vietnam.

Acknowledgment: This study was supported by the program grant from the collaboration project between Vietnam Academic of Science and Technology (VAST) and Far Eastern BranchRussian Academy of Sciences (FEB-RAS) (VAST.HTQT.NGA.13/16-17) and the project grant from No.3 branch component of the project 47 (VAST.ĐA47.12/16-19).

\section{REFERENCES}

Abdel-Aziz SM, Mouafi FE, Keera AA (2013) Extracellular metabolites produced by a novel strain Bacillus alveinrc-14: 6. heat-shock stress induces production of antimicrobial metabolites. J Basic Appl Sci Res 3: 410-420.

Bauer AW, Kirby WMM, Sherris JC, Turck M (1966) Antibiotic susceptibility testing by a standardized single disk method. Am J Clin Pathol 36: 493-496.
Bewley CA, Faulkner DJ (1998) Lithistid sponges: star performers or hosts to the stars. Angew Chem Int Ed 37: $2162-2178$

Carte BK (1996) Biochemical potential of marine natural products. Bioscience 46: 271-286.

Devi P, Wahidullah S, Rodrigues C, Souza LD (2010) The sponge-associated bacterium Bacillus licheniformis SAB1: A source of antimicrobial compounds. Mar Drugs 8: 12031212.

Dobler IW, Beil W, Long S, Meiners M, Laatsch H (2002) Integrated approach to explore the potential ofmarine microorganisms for the production of bioactive metabolites. Adv Biochem Eng 74: 207-238.

Faulkner DJ (2002) Marine natural products. J Nat Prod 19: 1-48.

Gebhardt K, Schimana J, Muller J, Fielder HP, Kallenborn HG, Holzenkampfer M, Krastel P, Zeeck A, Vater J, Holtzel A, Schmid DG, Rheinheimer J, Dettner K (2002) Screening forbiologically active metabolites with endosymbiotic bacilli isolated from arthropods. FEMS Microbiol Lett 217: 199-205.

Guo X, Zheng L, Zhou W, Cui Z, Han P, Tian L, Wang X (2011) A case study on chemical defense based on quorum sensing: antibacterial activity of sponge-associated bacterium Pseudoalteromonas sp. NJ6-3-1 induced by quorum sensing mechanism. Ann Microbiol 61: 247-255.

Ivanova EP, Vysotskii MV, Svetashev VI, Nedashkovskayal OI, Gorshkoval NM, Mikhailovl VV, Yumota N, Shigeri Y, Taguchi T, Yoshikawa S (1999) Characterization of Bacillus strains of marineorigin. Int Microbiol 2: 267-271. 
Jafarzade M, Yahya NA, Mohamad S, Usup G and Ahmad A (2013) Isolation and characterization of pigmented bacteria showing antimicrobial activity from Malaysian marine environment. Malays J Microbiol 9: 152-160.

Jayatilake GS, Thornton MP, Leonard AC, Grimwade JE, Baker BJ (1996) Metabolites from an Antarctic spongeassociated bacterium, Pseudononas aeruginosa. $J$ Nat Prod 59: 293-296.

Joseph S, Shanmughapriya S, Gandhimathi R, Seghal KG, Rajeetha RT, Natarajaseenivasan K, Hema TA (2009) Optimization and production of novel antimicrobial agents from sponge associated marine actinomycetes Nocardiopsis dassonvillei MAD08. Appl Microbiol Biotechnol 83: 435-445.

Kennedy J, Baker P, Piper C, Cotter PD, Walsh M, Mooij MJ, Bourke MB, Rea MC, O'Connor PM, Ross RP, Hill C, O'Gara F, Marchesi JR, Dobson ADW (2009) Isolation and analysis of bacteria with antimicrobial activities from the marine sponge Haliclona simulans collected from Irish water. Mar Biotechnol 11: 384-396.

Lie J, Zhou J (2002) A marine natural product database. $J$ Chem Inf Comput Sci 42: 742-748.

Mitova M, Tommonaro G, Rosa DS (2003) A novel cyclopeptide from a bacterium associated with the marine sponge Ircinia muscarum. Zeitschriftfur Naturforschung 58: 740-745

Mondol M, Shin H, Islam M (2013) Diversity of secondary metabolites from marine Bacillus species: Chemistry and biological activity. Mar Drugs 11: 2846-2872.

Nagai K, Kamigiri K, Arao N, Suzumura K, Kawano Y, Yamaoka M, Zhang H, Watanabe M, Suzuki K (2003) YM-266183 and YM-266184, novel thiopeptide antibiotics produced by Bacillus cereus isolated from marine sponge I. Taxonomy, fermentation, isolation, physicochemical properties and biological properties. $J$ Antibiot (Tokyo) 56: 123-128.

Nazar SS, Ravikumar G, Williams P, Syed AM, Suganthi P (2009) Screening of Indian coastal plant extracts for Larvicidal activity of Culex quinquefaciatus. Ind $J \mathrm{Sci}$ Technol 2: 24-27.

Pettit GR, Xu JP, Chapuis JC, Pettit RK, Tackett LP, Doubek DL, Hooper JN, Schmidt JM (2004) Antineoplastic agents. 520. Isolation and structure of irciniastatins A and B from the Indo-Pacific marine sponge Ircinia ramosa. $J$ Med Chem 47: 1149-1152.

Ravikumar S, Thajuddin N, Suganthi P, Jacob IS, Vinodkumar T (2010) Bioactive potential of seagrass bacteria against human bacterial pathogens. $J$ Environ Biol 31: 387-389.

Rinehart KL (2000) Antitumor compounds from tunicates. Med Res Rev 20: 1-27.
Sanchez S, Demain AL (2002) Regulation of fermentation processes. Enzyme Microb Tech 31: 895-906.

Santavy DL, Willenz P, Colwell RR (1990) Phenotypic study of bacteria associated with the Caribbean sclerosponge, Ceratoporella nicholsoni. Appl Environ Microbiol 56: 1750-1762.

Schwartsmann G, Rocha AB, Berlinck RGS, Jimeno J (2001) Marine organisms as a source of new anticancer agents. Lancet Oncol 2: 221-225.

Sfanos K, Harmody D, Dang P, Ledger A, Pomponi S, McCarthy P, Lopez J (2005) A molecular systematic survey of cultured microbial associates of deep-water marine invertebrates. Syst Appl Microbiol 28: 242-264.

Sneath PHA, Mair NS, Sharpe ME, Holt JG (1986) Bergey's manual of systematic bacteriology. 2: 965-1599.

Sonnenschein RN, Farias JJ, Tenney K, Mooberry SL, Lobkovsky E, Clardy J, Crews PA (2004) Further study of the cytotoxic constituents of a milnamide-producing sponge. Org Lett 6: 779-782.

Sreerag R, Jubi J, Nisha G, Asha A, Sasidharan N (2014) Influence of six nitrogen sources with fructose on antimicrobial metabolite production by bacterium associated with entomopathogenic nematode. Int J Pharm Pharm Sci 6: 299-304.

Suzumura K, Yoko T, Funatsu M, Nagai K, Tanaka K, Zhang H, Suzuki K (2003) YM-266183 and YM-266184, novel thiopeptide antibiotics produced by Bacillus cereus isolated from a marine sponge II. Structure elucidation. $J$ Antibiot (Tokyo) 56: 129-134.

Tabbene O, Slimene IB, Djebali K, Mangoni ML, Urdaci MC, Limam F (2009) Optimization of medium composition for the production of antimicrobial activity by Bacillus subtilis B38. Biotechnol Prog 25: 1267-1274.

Tareq FS, Lee Hyi-Seung, Lee Yeon-Ju, Lee JS, Shin HJ (2015) Ieodoglucomide C and Ieodoglycolipid, New Glycolipids from a marine-derived bacterium Bacillus licheniformis 09IDYM23. Lipids 50: 513-519.

Tareq FS, Lee MA, Lee HS, Lee YJ, Lee JS, Hasan CM, Islam MT, Shin HJ (2014) Non-cytotoxic antifungal agents: Isolation and structures of Gageopeptides A-D from a Bacillus strain 109GGC020. J Agric Food Chem 62: 5565-5572.

Unson MD, Faulkner DJ (1993) Cyanobacterial symbiont biosynthesis of chlorinated metabolites from Dysidea herbacea. Experientia 49: 349-353.

Unson MD, Holland ND, Faulkner DJ (1994) A brominated secondary metabolite synthesized by the cyanobacterial symbiont of marine sponge and accumulation of the crystalline metabolite in the sponge tissue. Mar Biol 119: 1-11. 


\title{
HOẠT TÍNH KHÁNG KHUẨN CỦA VI KHUẨN BIỄN CộNG SINH VỚI BỌT BIỄN THU TÙं ĐẢO PHÚ QUỐC, VIẸTT NAM
}

\author{
Phan Thị Hoài Trinh ${ }^{1, \bigotimes}$, Ngô Thị Duy Ngọcc ${ }^{1}$ Phí Quyết Tiến ${ }^{2}$, Lê Đình Hùng1, Võ Thị Diệu Trang ${ }^{1}$, \\ Cao Thị Thuý Hằng ${ }^{1}$, Huỳnh Hoàng Như Khánh ${ }^{1}$, Trần Thị Thanh Vân ${ }^{1}$, Bùi Minh Lý ${ }^{1}$
}

${ }^{1}$ Viện Nghiên cưu và Úng dụng Công nghệ Nha Trang, Viện Hàn lâm Khoa học và Công nghệ Việt Nam

${ }^{2}$ Viện Công nghệ sinh học, Viện Hàn lâm Khoa học và Công nghệ Việt Nam

\section{TÓM TẮT}

Vi sinh vật cộng sinh với bọt biển được xem là nguồn tiềm năng cho việc sàng lọc và phân lập các hợp chất có hoạt tính sinh học. Trong nghiên cứu này, ba mươi mốt chủng vi khuẩn biển cộng sinh với bảy loài bọt biển được thu từ đảo Phú Quốc, Việt Nam đã được phân lập và sàng lọc hoạt tính kháng khuẩn đối với các chủng vi khuẩn gây bệnh cho người và động vật bao gồm Escherichia coli, Pseudomonas aeruginosa, Staphylococcus aureus, Vibrio parahaemolyticus, Vibrio harveyi, Bacillus cereus, Streptococcus faecalis, Listeria monocytogenes, Proteus mirabilis và Klebsiella pneumoniae theo phương pháp khuếch tán trên đĩa thạch. Kết quả nghiên cứu cho thấy $26 \%$ chủng vi khuẩn biển có khả năng sinh chất kháng khuẩn và thể hiện hoạt tính kháng khuẩn đối với một số loài vi khuẩn gây bệnh (P. aeruginosa, E. coli, $P$. mirabilis, B. cereus, and L. monocytogenes). Trong số 31 chủng vi khuẩn được sàng lọc hoạt tính kháng khuẩn, 8 chủng thể hiện hoạt tính kháng khuẩn đối với ít nhất 2 chủng vi khuẩn kiểm định, cụ thể $55 \%$ kháng $P$. mirabilis, $22 \%$ kháng $P$. aeruginosa, $10 \%$ kháng $E$. coli và $6 \%$ kháng $K$. pneumoniae, B. cereus và $L$. monocytogenes. Chủng $045-$ 203-4 thể hiện hoạt tính kháng khuẩn mạnh nên được tuyển chọn cho nghiên cứu sâu hơn. Chủng vi khuẩn này sinh chất chuyển hóa có hoạt tính kháng khuẩn cao trong môi trường chứa dịch chiết nấm men $(0,8 \%)$, glucose $(0,5 \%)$, ở $\mathrm{pH} 7.0$ và sau nuôi lắc với tốc độ 150 vòng/phút trong 30 giờ. Bên cạnh đó, chủng 045-203-4 cũng được xác định một số đặc điểm hình thái và sinh lý. Định danh loài dựa trên so sánh trình tự 16s rRNA với một số chủng trên ngân hàng gen kết luận chủng này tương đồng $99 \%$ với trình tự $16 \mathrm{~s}$ rRNA của chủng Bacillus subtilis. Nghiên cứu cho thấy các chủng vi khuẩn phân lập từ bọt biển ở đảo Phú Quốc có thể xem là nguồn tiềm năng các chất kháng sinh mới.

Tù̀ khóa: Hoạt tính kháng khuẩn, Bacillus subtilis, Vi khuẩn biển, Chất chuyển hóa, Bọt biển, Vi khuẩn gây bệnh

\footnotetext{
Author for correspondence: Tel: +84-902793684; E-mail: phanhoaitrinh84@gmail.com
} 